\title{
Extreme Climate Events, Household Decision-Making and Transitions in the Immediate Aftermath of Hurricane Sandy
}

\begin{abstract}
It is five years since Hurricane Sandy heavily damaged the New YorkNew Jersey Metropolitan region, and the fuller character of the long-term response can be better understood. The long-term response to Hurricane Sandy and the flooding risks it illustrated are set in myriad of individual and collective decisions taken during the time following the event. While the physical vulnerability of this region to storm surge flooding and climate change risks including sea level rise has been well-documented within the scholarly literature, Sandy's impact placed decision-makingpost extreme events into the forefront of public and private discussions about the appropriate response.

Some of the most fundamental choices were made by individual homeowners who houses were damaged and in some cases made uninhabitable following the storm. These individuals were forced to make decisions regarding where they would live and whether Sandy's impact would result in their moving. In the disaster recovery and rebuilding context, these early household struggles about whether to leave or stay are often lost in the wider and longer narrative of recovery. To examine this early phase, this paper presents results of a research study that documented the ephemeral evidence of the initial phase of recovery in coastal communities that were heavily impacted by Hurricane Sandy's storm surge and flooding. Hurricane Sandy and the immediate response to the storm created conditions for a potential large-scale transformation with respect to settlement of the coastal zone. In the paper, we examine and analyze survey and interview results of sixty-one residents and two dozen local stakeholders and practitioners to understand the stresses and transitions experienced by flooded households and the implications for the longer term resiliency of the communities in which they are located.
\end{abstract}

Keywords

Extreme events $\bullet$ Hurricane Sandy $\bullet$ New York City $\bullet$ housing $\bullet$ resilience $\bullet$ transition

(c) University of Warsaw - Faculty of Geography and Regional Studies

Introduction

The New York Metropolitan Region's densely settled and developed coastal zone has high economic and ecological value yet is also recognized as increasingly vulnerable to storm surge flooding as a result of climate change and associated sea level rise. The vulnerability of this region to climate change has been well-documented within the scientific literature (e.g., New York City Panel on Climate Change 2015; Rosenzweig \& Solecki 2014). The impact of the 2012 Hurricane Sandy placed this issue into the forefront of public and private discussions about the appropriate response at every level from individual homeowners and local business owners who are contemplating rebuilding after devastating losses, to small coastal municipalities which are considering construction of protective engineering structures, green infrastructure, and changes in zoning laws and planning regulations, to the City of New York, and the states of New York and New Jersey along with the federal government which are engaging in discussions about construction of large scale, storm surge barriers to protect the region's population, property, and vital infrastructure. The dominant narrative of the response was not to retreat from the

\author{
William Solecki', Robin Leichenko², \\ David Eisenhauer ${ }^{3}$ \\ 'Department of Geography, Hunter College - \\ City University of New York, US \\ e-mail: wsolecki@hunter.cuny.edu \\ 2Department of Geography, Rutgers University, \\ New Brunswick, NJ, US \\ e-mail: rleichen@geography.rutgers.edu \\ ${ }^{3}$ Department of Geography, Rutgers University, \\ New Brunswick, NJ, US \\ e-mail: davidceisen@gmail.com \\ Received: 22 November 2017 \\ Accepted: invited paper
}

coast but to rebuild in a more resilient fashion. Even so, individual property owners of damaged homes have had to wrestle with the question of whether or not to rebuild or relocate and how would they afford any decision they make. These residents, in effect, entered into a transition with respect to their land tenureand were forced to contemplate the possibility of dislocation.

The specific objective of this study is to define the conditions of this transition among the residents of coastal communities that were heavily impacted by Sandy's storm surge and flooding including the role of household and community context variables such as post-event property buyout programs or rezoning policies focused on limited redevelopment of parcels in high storm surge sites. The paper attempts to define early warning signals of such system transition in the post disaster context and identify what are those early response events that have significant implication as to whether change in a local social-ecological system takes places. The months following Hurricane Sandy provide a brief window of opportunity to investigate early-stage transition processes in large, coastal urban regions experiencing the impacts of climate 
change. The early response to Hurricane Sandy in the New YorkNew Jersey Metropolitan Region appears to signal a break from how extreme events were understood in the past both within this region and throughout the heavily urbanized Middle Atlantic and Northeast coastal zone (NPCC 2015).

We argue that the seeds of a large-scale transformation of the metropolitan region's coastal settlement system are planted in the early discussions and actions following the large-scale shock brought on by Hurricane Sandy. To address this assertion we draw from resilience theory, social-ecological systems (SES) analysis on how natural or human-natural coupled systems respond to shocks and stresses (e.g., Scheffer 2009; Lenton 2011;Carpenter \& Scheffer 2009; Folke 2006; Walker et al. 2004; Gunderson \& Pritchard 2002; Gunderson \& Holling 2001).

Operationally, the paper investigates the potential impact of Hurricane Sandy on settlement patterns and development trajectories in heavily impacted coastal zones of the states of New Jersey and New York. We investigate these questions in five study sites - three in New Jersey (in the communities of Old Bridge, Sayreville and South River) and two in New York State (Midland Beach and New Dorp Beach neighborhoods on Staten Island that is part of New York City).

The research attempts to determine whether one can identify early signals of transition and transformation in the housing decisions of homeowners and communities affected by Hurricane Sandy. The analysis focuses on two central research questions: 1 . What stress and crisis conditions did local homeowners face as a result of Hurricane Sandy?; and 2. What do the early post extreme event responses of homeowners to Hurricane Sandy illustrate about their resilience. The first question explores the socio-ecological system stress and crisis being faced by coastal property owners during this early recovery phase in communities highly-impacted by Hurricane Sandy, and the association between this type of stress and crisis and shifts in system state equilibrium (i.e., defined how well the individual households impacted by Hurricane Sandy were ablefunction and carry out their everyday activities). In the analysis, different subsets of respondents are examined based on their response to the storm's impact - these sets are defined from the resiliency literature. Two of which include situations in which the residents of households remain in their home following the event and rebuild. Those households that simply focus on rebuilding as before are seen as bouncing back and not enhancing their own resiliency and instead defined as using a resistant risk management strategy (see Solecki et al. 2017 for more discussion of risk management regimes). Those that remain yet are determined to rebuild in way to be more resilient to future storms are defined as bouncing forward. The second category is comprised of households that decided to seek a property buyout in order to move or bounce away. These households are defined as going through a "transition", thereby a shift from one system state to another. The second question examine whether there are system-level and cross-scale connections between homeowner responses and those of their neighbors?

Climate change has raised the specter of climate risk related dislocation. Large-scale climate induced dislocation has been described a variety of settings including villages in the high arctic (Hamilton et al. 2016), semi-arid grasslands, water resource shortage prone sites, and small island nations (Nakayama et al. 2016), as well as along coastlines where sea level rise is expected to dramatically alter the flood frequency and intensity (Hauer et al. 2016). In areas along the U.S. east coast many sites are starting to experience an increase in nuisance flooding (e.g. flooding occurring during lunar high tides) (Ankum et al. 2016). Concern regarding shifts in property value has begun to increase. In a more dramatic case, inland less flood prone sites are becoming taken over by wealthier residents in metropolitan regions who have property in high-risk locations and are seeking out the security of higher ground locations. In Miami-Dade, reports have documented substantial residential shifts already taking place with wealthier residents buying properties of inland higherground, lower income residents in advance of accelerating sea level rise (Vasilogambros 2016).

The loss of residence and community, besides personal injury and death of a relative or close friend, is one of the most traumatic results of an extreme event or disaster. Geographers and other have well documented the effects of such dislocation and loss of sense of place (Relph 1976). The important difference in the current era of climate change is that the environmental risk baseline of coastal communities has begun to change. As a result, even those who are able to recover from the damaging effects of a coastal storm and remain in their homes increasingly recognize that ongoing sea level rise is resulting in heightened storm surge elevation and frequency of flooding, and as a result their homes are under more and more risk.

\section{Extreme Events, Post Disaster Decision-Making and Transitions}

Geographers have long examined the impacts of extreme events particularly natural and technological hazards on local populations and the broader society. It is well recognized that extreme events can become a significant shock to communities and often combine with underlying stressors and can result in shifts and changes in the composition, structure, and development trajectory of localities. While a variety of analysis frames have been used to understand the immediate and longer-term implications of extremes. These analyses have been very useful for illustrating the connections between social, economic and political conditions and the level and nature of societal response and change. Change or transition can be defined here as a shift in investment, residence, or other metric of status (e.g., loss of political power, alteration of land use change patterns).

A key goal of this research is to understand what triggers change in a community, and what conditions set in motion a trajectory of change. Change here is defined as suite of adjustments potentially punctuated by a transition in which the dominant system structure of the community in question can transform. A connected issue is what has been a trigger for change in the past. Given the context of climate change, it is commonly understood that the response to Hurricane Sandy will be different from past responses. The question that remains is whether or not the response to Hurricane Sandy is in fact significantly different. If it is different -why is different, how and to what extent? The answers to these questions could provide valuable insight into what are the lessons learned for understanding future opportunities for social-ecological system change in the context of climate change.

\section{System Transitions}

Systems are inherently dynamic but under "normal" conditions operate within a range. Systems can and do however change dramatically and transitions from one state to another. Scheffer and others (2009; 2012 et al.) define three types of transitions. In the first type, transitions occur as a result of a large-scale external change (like an extreme weather event) that causes a decline of the system state equilibrium while the system, itself, maintains the capacity to gradually recover. In the second type, a transition results from a smaller scale perturbation that forces the system past a non-critical system threshold, from which there is a high probability that the system could recover. The third type is defined as a critical transition which includes a catastrophic bifurcation where even a relatively small additional shock or stress pushes 
the system past a threshold (or tipping point) resulting in a significant shift and break in the system equilibrium line. This change is so profound that the system enters into a regime shift or phase change during which the function and quality of the system shifts from one state to another.

The current paper attempts to identify and illustrate the role of ephemeral conditions that link together driver and contextual variables that in turn generate change. Pelling's (2015) asserts that within the context of risk management system, the adaptation activity sphere is a site where these changes can take place. Solecki (et. al. 2017) that risk management system change takes place as a result of a variety of variety of driver and contextual variables including root, proximate, and direct factors. We assert that the role and position of the driver and contextual variables can change within the adaptation activity sphere. The drivers and context can become differently influenced under certain conditions increasing or decreasing the likelihood that the system will change. A critical research question to be addressed is what are the conditions of social-ecological-system change and what specific aspects of the activity space and context are more likely to influence the likelihood of a system change. For case presented here we examine the transition of a household as a SES.

Three broad groups of geographic research are incorporated to understand the process of change or transition amongst post event decision makers. These include hazards theory (which includes rational choice and behavioralist approaches), political economy (ecology), and resiliency theory. Each approach takes a different perspective on the relationship between extreme events and societal response (see Figure 1).

\section{Hazards Theory}

Many current climate change studies and examinations of extreme events are looking at the contemporary era to understand ongoing climate actions and potential future exposures and vulnerabilities, and barriers and opportunities for future actions (e.g. Solecki et al. 2011).Studies such as these are while worthwhile given their applied and on-the-ground context. Initially the hazards research within geography was largely atheoretical where the relative size of the hazard event dictates the extent of the societal response - the larger the event then the larger the impact (Burton et al. 1993). This approach did not yet problematize underlying social, economic, and political constraints needed for meaningful action and transformation. System state variables include basic metrics of socio-economic well-being, population dynamics, and measurement of change since the extreme event.

\section{Political Economy (Ecology)}

A basic early political economy critique of hazards literature was the role of institutional and economic constraints and inequities were not fully incorporated (e.g., Hewitt 1983; Wisner et al. 2003). These critiques focused on the social construction of the risk and hazards themselves and differential capacity of individuals, institutions, and communities to respond to extreme event once they occur. The approach of hazards research presented by political ecology provides a synthesis where the conditions of physical environment and societal context can be integrated. Theoretically, the relationship between extreme events and response are heavily context specific as a result it could be difficult to define a consistent or directional relationship between the two conditions. System state variables are defined as those associated with hazardousness of place and differential role and conditions of social vulnerability.

\section{Resiliency Theory}

The resiliency of a household in response to an extreme event is a function of the internal qualities and characteristics of
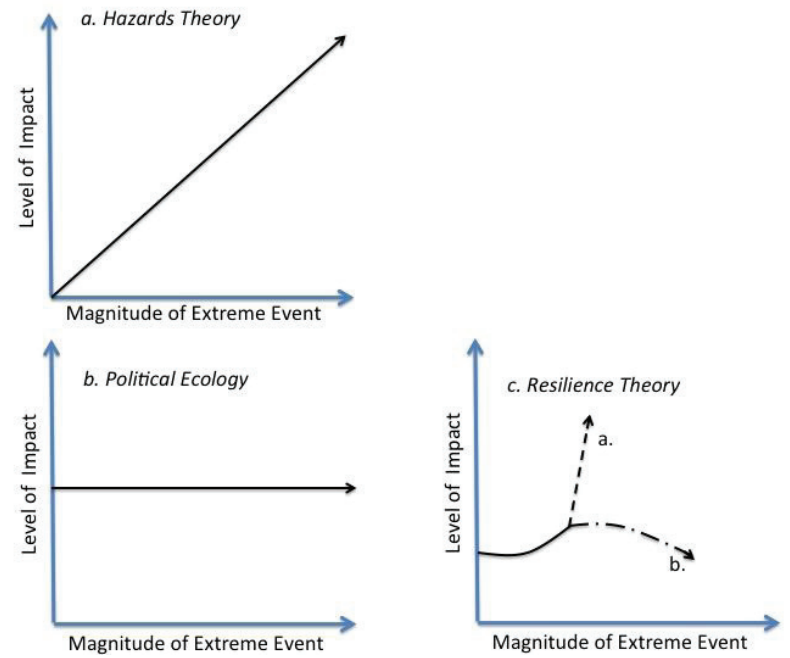

Figure 1. Transitions in equilibrium state (line) response to different types of perturbations.

the households and how they can be mobilized during an post event context, the condition of the larger community in which it is located and the connections between the household and the community. Positive and negative feedbacks effects influence the household resilience and the likelihood of transition and that of the community as well. Extreme events and the resiliency have a series of complex interaction. In systems with high resiliency, the capacity to withstand or recover from a shock is typically high. Systems with lower resiliency are more subject to the possibility of a catastrophic system change because the shock could overwhelm the structural integrity of the system and the system would not be able to recover its equilibrium.

\section{Raritan Bay Communities and the Impact of Hurricane Sandy}

The Raritan Bay in many ways is a prototypical urbanized coastal setting in the eastern U.S. The first European settlement occurred in early part of the $17^{\text {th }}$ century followed by phases of economic development and associated ecological transformations. The Bay is divided between two U.S. states. The border separating New York and New Jersey runs down the middle of the bay. The bay is cone shaped with the widest point open to the New York Harbor and the New York Bight (Atlantic Ocean) in the east, running to a fine point $22.5 \mathrm{~km}$ to the west. The New York side of the bay is the southern shore of Staten Island (Richmond County); the counties of Middlesex and Monmouth form the New Jersey shoreline and the Raritan River enters the Raritan Bay from New Jersey between the city of Perth Amboy and South Amboy (see Figure 2). On Staten Island, a low-lying coastal region stretches between the shoreline Raritan Bay and the elevated interior of the island (Sparberg 2010). The New Jersey side includes extensive coastal wetlands, bluffs and interior highlands.

Seventeenth century colonial settlementswere focused on fishing and oyster harvesting within the bay and environs (Mackenzie 1992; McCay 1998). By the early $20^{\text {th }}$ century, however, industrial pollution and overfishing dramatically decreased the economic viability of commercial fishing in the bay and ended the previously lucrative oyster industry (MacKenzie 1992). Through the $20^{\text {th }}$ century, the area surrounding the Raritan Bay became increasingly industrialized and urbanized. A number of oil refineries and factories were built along the interior waterways in 


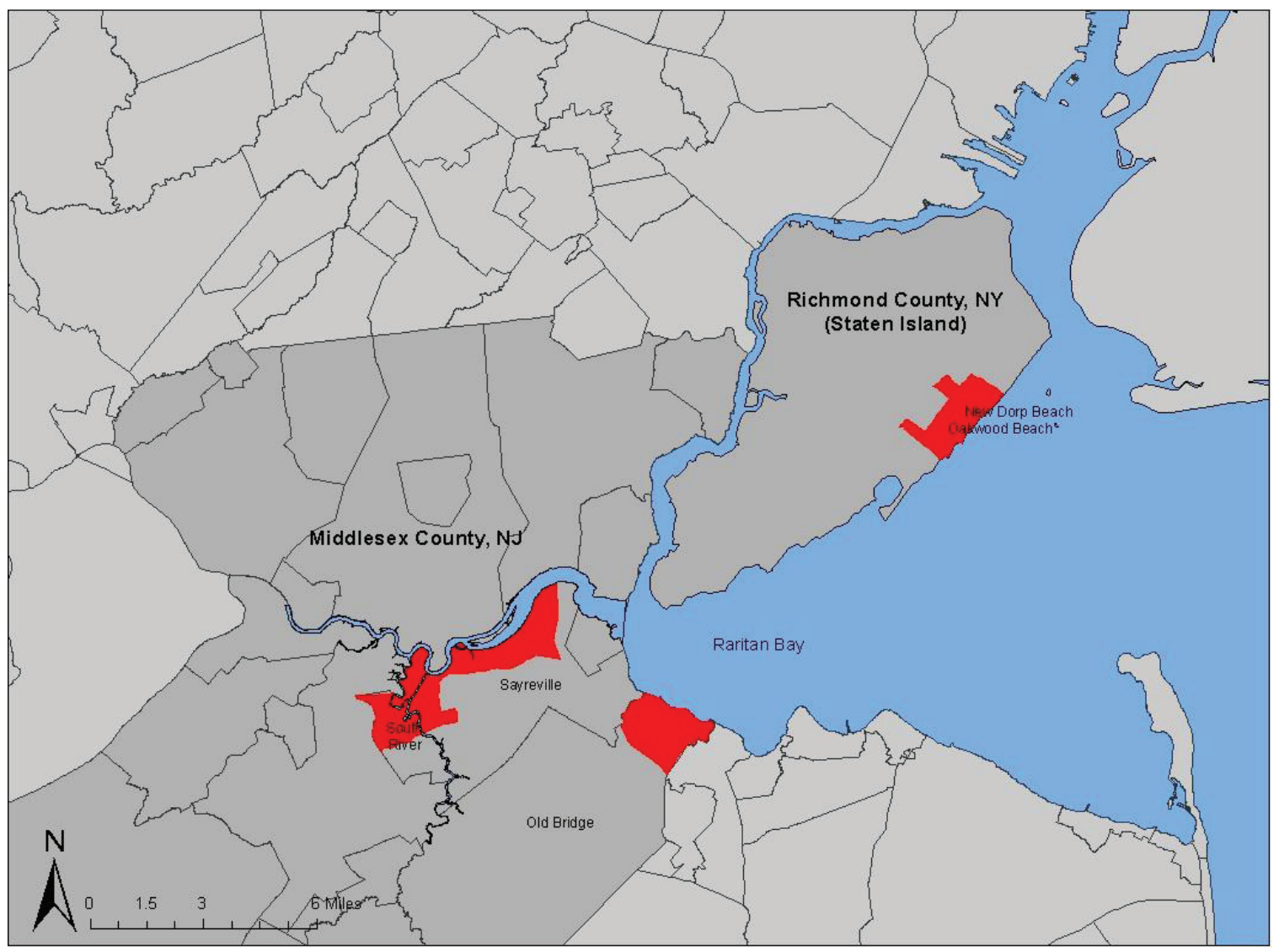

Figure 2. Map of Raritan Bay Region

the early $20^{\text {th }}$ century. As part of the legacy of these developments, several U.S. Federal government-designated Superfund sites are located along Raritan Bay or the immediate waterways feeding into the bay.

The importance of industry has declined in the region during the past few decades. However at the same time, residential population within region especially near the water's edge has grown dramatically. Since 1900, population growth in Middlesex County and Monmouth County has exceeded the population growth rate of the rest of New Jersey (Mitchell 2006). From 1900 to 2013 , Middlesex Country grew $840 \%$ from 79,762 people to 836,297 people. Monmouth County grew $650 \%$ from 82,057 people to 629,672people during that period (US Census Bureau 2014; Forestall 1996). Partially due to this development, both Middlesex County and Monmouth County have experienced a higher conversion rate of wetlands to development compared to the New Jersey average (Lathrop \& Hasse 2006). On the New York side of the bay, Staten Island also has grown over the past century. Though it remains the least populated borough of New York City, Staten Island grew from a population of 67,021 in 1900 to 472,621in 2013 (US Census Bureau 2014; Forestall 1996).

The Raritan Bay region is subject to the impacts of coastal storms including hurricanes and nor'easters. Although the 1938 hurricane was the last major storm surge event before Hurricane Sandy, the Bay communities also were significantly affected by the 1944 hurricane, 1960 Hurricane Donna, and the 1962 and 1992 nor-easters. Hurricane Sandy caused the second most economic damage in the United States of any cyclone since 1900 with Hurricane Katrina in 2005 the first. In the United States, the
Sandy resulted in seventy-two direct deaths and eighty-seven indirect deaths, an estimated $\$ 50$ billion USD in damages, and destroyed or damaged at least 650,000 houses (Blake et al. 2012). The storm made landfall in the U.S. just north of Atlantic City New Jersey as a post-tropical cyclone. Coastal areas of the New York metropolitan region experienced wind, heavy rain, and storm surge (Blake et al. 2012; NPCC 2013) (Figure 3). The storm is currently estimated to represent a several hundred year event (Aerts et al. 2013; Hall \& Sobel 2013; Rosenzweig \& Solecki 2014).

Sandy's landfall coincided with high tide in many areas, which contributed to the record levels of storm surge and inundation experienced in the Raritan Bay region. The highest measurement of above ground flooding was 2.4 feet in the Oakwood neighborhood of Staten Island (see table 2) (Blake et al. 2012). The neighborhoods Oakwood, Midland, and New Dorp lost entire blocks of homes to storm damage and at least twenty-one people died in Staten Island from storm surge (Blake et al. 2012). Over $90 \%$ of the homes in the neighborhoods were impacted by the storm (Hughes 2015). On the New Jersey side of the bay, the town of Keyport reported a high-water mark of 2.4 feet of storm surge. The surge also pushed water up the Raritan River, which caused a high water mark of 2.3 feet above ground level in Sayreville several miles upstream from its outlet into the bay (see Table 2) (Blake et al. 2012).

The New Jersey state government initially estimated $\$ 31.8$ billionUSD in funding needs to respond to Hurricane Sandywith about $\$ 25.5$ billion USD for infrastructure and community facilities (NJ DCA 2013). 40,500 primary residences and 15,600 rental units sustained severe or major damage in New Jersey. 


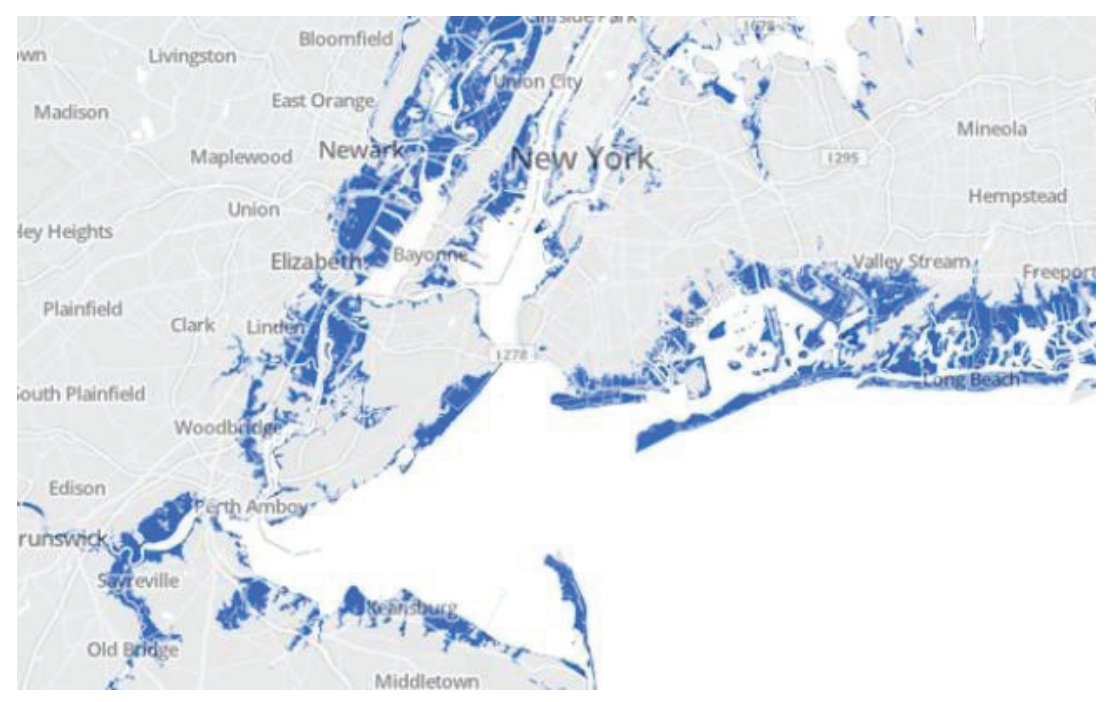

Figure 3. Flood Inundation Area - derived from the City Lab website

Table 1. Selected Demographics for the Case Study Locations (source: U.S. Census Bureau)

\begin{tabular}{|c|c|c|c|c|c|}
\hline & Total Population & $\begin{array}{c}\text { Percent } \\
\text { Non-White }\end{array}$ & $\begin{array}{c}\text { Median } \\
\text { Household } \\
\text { Income }\end{array}$ & $\begin{array}{c}\text { Owner- } \\
\text { Occupied } \\
\text { Housing }\end{array}$ & $\begin{array}{c}\text { Median Value of } \\
\text { Owner-Occupied } \\
\text { Units }\end{array}$ \\
\hline \multicolumn{5}{|c|}{ New Jersey } \\
\hline Middlesex County & 809858 & $41.40 \%$ & $\$ 79,442$ & $66.60 \%$ & $\$ 349,000$ \\
\hline Sayreville & 42704 & $31.40 \%$ & $\$ 78,622$ & $68.90 \%$ & $\$ 338,900$ \\
\hline Sayreville Study Tracts & 8073 & $23.51 \%$ & $\$ 90,104$ & $85.88 \%$ & $\$ 313,605$ \\
\hline South River & 16008 & $20.90 \%$ & $\$ 64,721$ & $71.10 \%$ & $\$ 331,900$ \\
\hline South River Study Tracts & 16008 & $23.82 \%$ & $\$ 61,640$ & $66.55 \%$ & $\$ 293,274$ \\
\hline Old Bridge & 23753 & $20.40 \%$ & $\$ 97,738$ & $86.30 \%$ & $\$ 357,500$ \\
\hline Old Bridge Study Tracts & 6536 & $19.83 \%$ & $\$ 75,172$ & $74.40 \%$ & $\$ 270,000$ \\
\hline \multicolumn{7}{|c|}{ New York } \\
\hline Richmond County & 468730 & $36.00 \%$ & $\$ 72,752$ & $67.30 \%$ & $\$ 456,100$ \\
\hline Oakwood Wood Tracts & 14930 & $13.03 \%$ & $\$ 70,337$ & $65.61 \%$ & $\$ 439,263$ \\
\hline Midland Beach Tracts & 15636 & $15.19 \%$ & $\$ 74,164$ & $76.45 \%$ & $\$ 433,855$ \\
\hline
\end{tabular}

Another 19,505 properties experienced minor damage (NJ DCA 2013). For New York City, 11\% of residents lived in areas that experienced flooding (NYC 2013). The City of New York estimates that Sandy caused $\$ 19$ billion in damages across the public and private sectors (SIRR 2013).

Household Responses in the Early Post-Extreme Event Period

Stakeholder surveys were conducted in three New Jersey towns (Sayreville, South River, and Old Bridge) and two Staten Island neighborhoods (Oakwood Beach and Midland Beach) (see Table 1). The sites were selected as representative of Raritan Bay communities affected by Sandy. The census tracts in which the survey respondents lived can be generally described as low- to moderate-income New York and New Jersey coastal communities with land uses dominated by single-family and some multi-family residences and a small number of commercial and industrial sites. The population was relatively diverse with respect to race/ethnicity, age, and employment. Household surveys were performed on blocks with houses damaged by floodwater, as noted by local planners and available storm surge inundation maps.
On the New Jersey side, the towns of Sayreville and South River are largely residential with small pockets of industrial zoning. The average incomes and property values in Sayreville exceed those found in South River. In Sayreville, the census tracts within which surveys were conducted had a higher income level than the town average; whereas, in South River the census tracts had lower than average incomes. Surveys also were conducted in the Laurence Harbor area of the Old Bridge Township. Old Bridge Township has the highest household income of any area studied, but the Laurence Harbor area's average household income is more than $\$ 20,000$ less then the rest of the township. Most of Laurence Harbor consists of a dense neighborhood of small single-family homes at elevations above the storm surge height. A small cluster of homes at the northern end of the area, closer to sea level, was devastated during Hurricane Sandy, and included in the survey sample.

Hurricane Sandy also heavily affected several neighborhoods on the Staten Island side of the bay. The neighborhoods to survey were derived from discussions with local and city stakeholders and assessments of overall storm damage. The Oakwood Beach and 
MISCELLANEA GEOGRAPHICA - REGIONAL STUDIES ON DEVELOPMENT

Vol. $21 \cdot$ No. 4 • 2017 • pp. 139-150 • ISSN: 2084-6118 • DOI: 10.1515/mgrsd-2017-0029

Midland Beach neighborhoods are adjacent to each other, and have similar demographics, income levels, and property values. Compared to the rest of Staten Island, these neighborhoods have a much lower percentage of non-white residents. In the early $20^{\text {th }}$ century, the area was a popular tourist and recreation destination with a boardwalk and casino. While public access beaches are still present in the area, the popularity of beaches declined steeply after WWII due to increased frequency of acute water pollution events. Pollution levels have decreased in recent years and the beaches have regained some popularity. The area is now largely residential and with some commercial properties. Population in the area increased significantly after the VerrazanoNarrows Bridge was finished in 1964 (Johnson 2010; Sparberg 2010) directly connecting Staten Island to the rest of the New York City.

On Staten Island, Hurricane Sandy damaged approximately 6,802 homes with 2,232 and 1,626 in the New Dorp-Midland Beach and Oakwood Beach neighborhoods respectively. In Middlesex County, New Jersey 1,975 homes were damaged, 208, 1078, and 437 in Old Bridge, Sayreville, and South River respectively (source: Newark Star Ledger).

Several sources of data were used for the analysis of the neighborhoods. The key material was derived from survey interviews with homeowners in New York and New Jersey communities in the Raritan Bay region. Sixty-one heads of households were interviewed through the use of close and openended survey instrument between July and December 2013. Questions relating a range of variables were asked (see Table 2) to determine the level of stress households faced, resources available to them, and their decision-making process. Interviews were conducted with local planning and development officials to provide additional context for the survey results. Approximately two-dozen such respondents were asked questions in a semistructured context. Additional contextual information from local newspapers, local group websites, and social media were collected and analyzed. Simple descriptive statistics and comparative means statistics were calculated to reveal the association and differences among the sample of respondents. The interviews and secondary data were analyzed for latent and manifest content and were used to provide construct validation of the survey results.

The average age the respondents $(n=61)$ was just over 50 years of age, and average length of residence within each home was approximately 20 years - both higher than average for the wider area.For almost all residents, the property damaged was their primary residence and they owned the home. Forty one percent of the respondents had a high school diploma or equivalent as their terminal degree while about a third had a college degree or more education. The New York and New Jersey samples were statistically compared and were found not to be statistically different and as such considered as a single sample.

\section{Stress and Crisis of Households}

The most heavily impacted Raritan Bay residents were struggling to recover after the flooding, and faced significant financial, social and emotional stress. Half of the homeowners surveyed had forced to leave their homes for an extended period (avg. time this took was four months); almost all of residents had incurred significant damage and $77 \%$ of the homes were left uninhabitable post-Sandy for an extended period. ${ }^{1}$ Seventy percent relocated to the homes of nearby friends and family. The mean amount of damage for each residence including damage to their home and other property was a bit over $\$ 110,000$ USD. At the time of the survey, insurance claims had covered on average only approximately $\$ 51,400$ USD of the damages. Each household had used approximately $\$ 22,100$ USD of household

${ }^{1}$ These individuals were interviewed during a visit to their home during which they were doing repairs.
Table 2. Variables defined within the household survey

\begin{tabular}{|c|c|}
\hline Variable List & Range \\
\hline \multicolumn{2}{|l|}{ Impact } \\
\hline 1. Evacuated & $0 / 1$ \\
\hline 2. Home Damage & $0 / 1$ \\
\hline 3. Home Uninhabitable & $0 / 1$ \\
\hline 4. Number of weeks displaced & \\
\hline 5. Still displaced & $0 / 1$ \\
\hline 6. Number of days displaced & interval \\
\hline $\begin{array}{l}\text { 7. Total damage and loss (house, property, } \\
\text { secondary) }\end{array}$ & interval \\
\hline \multicolumn{2}{|l|}{ Resiliency } \\
\hline 8. Stayed with friends and family & $0 / 1$ \\
\hline $\begin{array}{l}\text { 9. Amount compensated (Govt. aid, insurance, } \\
\text { other) }\end{array}$ & Interval \\
\hline 10. Amount of saving used & Interval \\
\hline 11. Years owned property & Interval \\
\hline 12. Number in household & Interval \\
\hline 13. College or graduate school resident & $0 / 1$ \\
\hline 14. Household income $>75 \mathrm{k}$ & $0 / 1$ \\
\hline 15. Decided with a week on what to do & $0 / 1$ \\
\hline \multicolumn{2}{|l|}{ Change in Resiliency } \\
\hline 16. Concern paying expenses & 1 to 5 \\
\hline 17. Concern dislocation of household members & 1 to 5 \\
\hline 18. Concern of lack of recovery information & 1 to 5 \\
\hline 19. Distress on loss of community & 1 to 5 \\
\hline 20. Stayed more than 30 minutes from house & $0 / 1$ \\
\hline \multicolumn{2}{|l|}{ Transition } \\
\hline 21. Resistant - Staying - repair to pre-Sandy & $0 / 1$ \\
\hline 22. Resilient - Staying - repair as more resilient & $0 / 1$ \\
\hline $\begin{array}{l}\text { 23. Selling and Buyout (As is, with repair, } \\
\text { buyout) }\end{array}$ & $0 / 1$ \\
\hline 24. Undecided & $0 / 1$ \\
\hline 25. Already Sold & $0 / 1$ \\
\hline \multicolumn{2}{|l|}{ Control Variables } \\
\hline 26. State of Residency & String \\
\hline 27. Municipality of Residency & String \\
\hline 28. Census Tract & String \\
\hline
\end{tabular}

savings responding to the damage. Together, these two sources accounted for roughly two-thirds of the reported damage. Several variables illustrated social and emotional stress of the respondents. The residents were somewhat concerned about a loss of sense of community post Sandy (avg. 2.98 out of 5.0the highest level) and a general lack of information about the recovery process (avg. 3.07). Less concern was present over the dislocation of household members (2.28) and the capacity to pay for household expenses (2.52).

Residents spoke of personal experiences during the storm and the recovery period. Many remained traumatized over their experiences and those of family members during the storm' and 


\section{Certainty about Post-Sandy Decision}

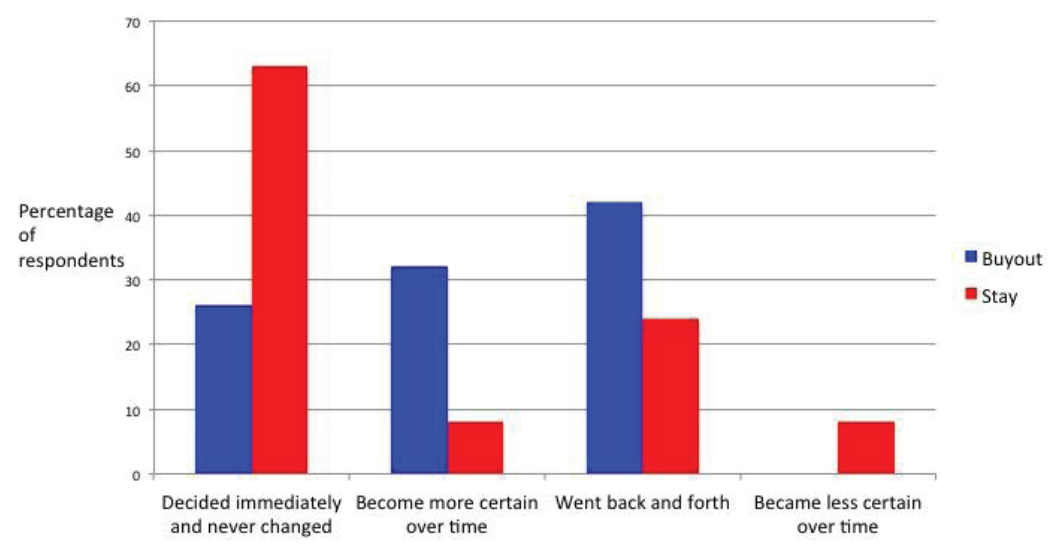

Figure 4. Post Sandy decision making - certainty

\section{Time to Decision after Sandy}

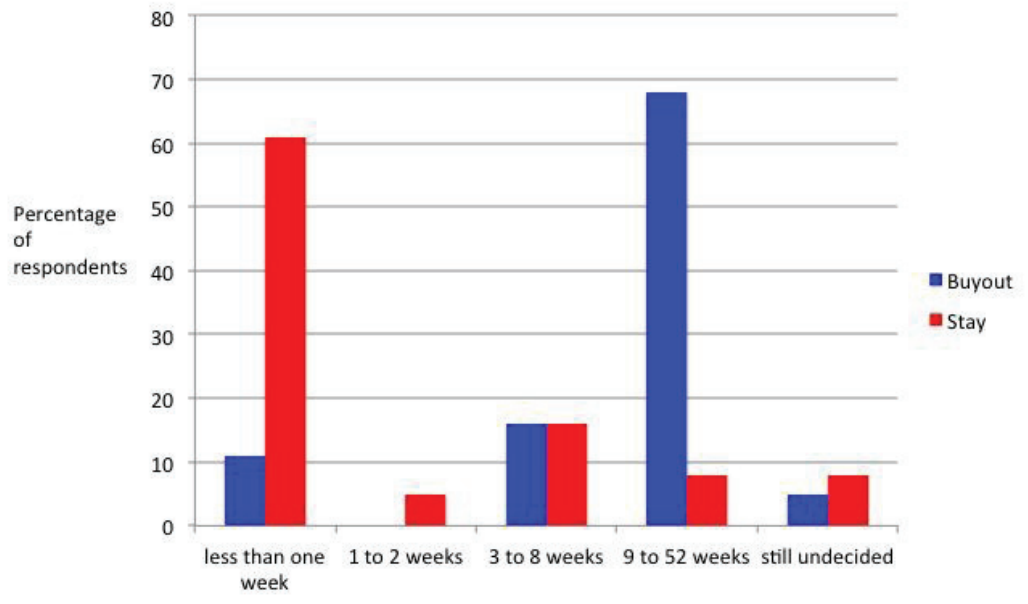

Figure 5. Post Sandy decision making - time

its aftermath. Stories of self-reliance and criticism of government information sources and programs were dominant. For some, community residents became greedy and selfish while others experienced an enhanced community spirit. The residents were concerned about increasing insurance rates and their ability to pay them. Residents who owned semi-attached or attached homes were particularly stressed; because, they could only act in concert with their neighbors. In one case, the household resident wanted to seek a buyout but her two attached neighbors (one house on either side) did not want to leave.

\section{Household Resilience and Transition}

About two-thirds $(n=41)$ of the household residents wanted to stay in their home and the rest ( 20 homeowners) sought buyouts or were in the process selling. Moving particularly when driven by factors such as a natural disaster can be considered to be significant household transition. More than half of the household decided within the first week following the storm whether to remain in their house or not, although many decided over a longer period of time with some still undecided over a year out. Almost all those who decided what they wanted to do in the first two weeks after the storm, said that they had decided to stay, while those who wanted the buy-out option decided this later in the process (almost $70 \%$ decided only after nine weeks following the storm). Roughly half of the households eventually decided to leave their home and relocate out of the immediate vicinity (Figures 4 and 5).

The comparative means tests show that there are several areas where there is statistically significant difference between those households planning to stay and those planning to leave their home (see Tables 3 and 4).

Those who decided to seek a buyout also were dislocated from the home longer, had lived in their home longer, and were older than other non-buyout seeking residents. Other factors distinguishing these residents from others was that there were more likely able to access other forms of insurance besides flood 
MISCELLANEA GEOGRAPHICA - REGIONAL STUDIES ON DEVELOPMENT

Vol. $21 \cdot$ No. $4 \cdot 2017 \cdot$ pp. 139-150 •ISSN: 2084-6118 • DOI: 10.1515/mgrsd-2017-0029

Table 3. Comparative Means - T-test (circle variables indicate those that where the difference is statistically significant)

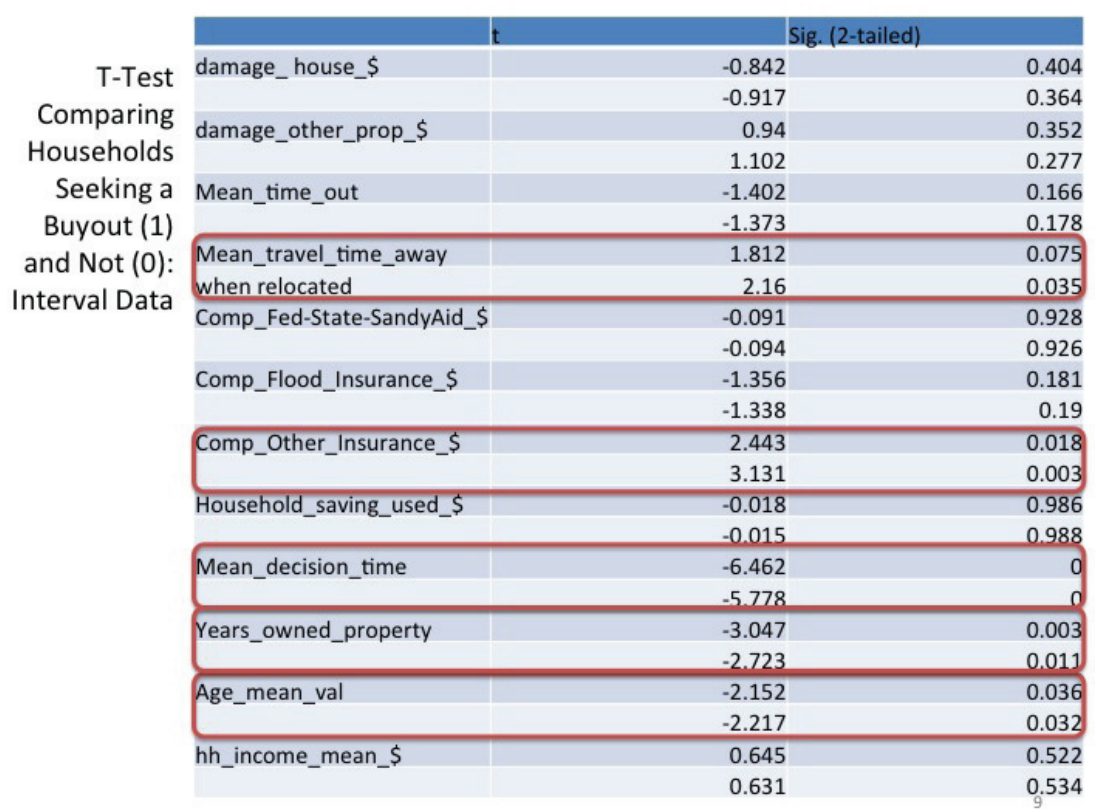

Table 4. Comparative Means T-test (circle variables indicate those that where the difference is statistically significant)

\begin{tabular}{|c|c|c|c|}
\hline & & & \\
\hline & Concern_paying_hh_expenses & 0.854 & 0.397 \\
\hline & & 0.865 & 0.393 \\
\hline T-Test & Concern_disloc_hh_members & 1.709 & 0.093 \\
\hline Comparing & & 1.793 & 0.08 \\
\hline $\begin{array}{r}\text { Households } \\
\text { Seeking a }\end{array}$ & $\begin{array}{l}\text { Distress_bc_loss_sense_of_com } \\
\text { munity }\end{array}$ & -0.584 & 0.562 \\
\hline Buyout and & & -0.593 & 0.557 \\
\hline $\begin{array}{r}\text { Not: } \\
\text { Ordinal Data }\end{array}$ & Info_neighbors & 0.903 & 0.37 \\
\hline & & 0.796 & 0.433 \\
\hline & Info_fam-friends & -1.24 & 0.22 \\
\hline & & -1.209 & 0.234 \\
\hline & Info_local_gov & -3.293 & 0.002 \\
\hline & & -3.703 & 0.001 \\
\hline & Info_state_gov & -3.025 & 0.004 \\
\hline & & -3.157 & 0.003 \\
\hline & Info_fed_gov & -2.052 & 0.045 \\
\hline & & -2.222 & 0.031 \\
\hline
\end{tabular}

insurance and were much less likely to get their information on what was happening in the post event context from government (local, state, or federal) information sources. Factors such as household income and damage costs were not significantly different in the two groups.

Households that soughta buyout were asked about a series of factors that influenced their decision to relocate. The respondents felt most strongly that the time and effort to rebuild, the current storm risk, and that their perception that the future risk would be worse were the strongest factors $(4.33 ; 4.81$; and, 4.52 out of 5.00 respectively). Homeowners seeking a buyout were more likely to waver back and forth in their decision-making process before ultimately seeking buy-outs. Wavering in decision-making could be described as similar to a flickering (on - off - on again) process consistent of a system in a potential crisis and undergoing a critical transition (see Scheffer 2009 for discussion on this process). Overall no significant shiftswere found in social network capacity although in a few cases, individual felt it was declining. A case-by-case analysis reveals that those with less social networking capacity were found to be more likely interested in selling.

\section{Bounce Back, Forward, or Away}

The respondents were facing a variety of stresses in the post Sandy context and their decision-making and action during this 
time reflects the household's underlying resiliency and capacity to recover. Approximately half of the residents were intent on staying and repairing their homes to level that was present before the storm. The other half intended either to make their homes more resilient than pre-Sandy conditions ( $15 \%$ of all households) or relocate ( a third of all households). The decision to build with added structural resiliency or relocate post Hurricane Sandy both illustrates a household system level change. For each of these households, their decision-making show that the prior condition of everyday life would be not sustained - either by choice or a set of externally determined conditions. Several factors associated with these shifts were examined in the survey questions. They include the diminished resiliency capacity, loss of social cohesion and community, and lack of decisiveness (i.e., flipping back and forth or flickering).

Each resulting decision -1. Rebuild and remain (i.e., bounce back); 2. Rebuild more resilient and remain (i.e., bounce forward); and 3. Relocate (i.e. bounce away) can be associated with different resiliency contextsand specific household attributes. To rebuild and remain illustrates the resiliency of the status quo. A household in this categoryhas the system level resiliency to recover, rebuild and remain in situ. The household that decided to rebuild while attempting to make their residence better to withstand future hazards and disaster defines a system which is able to learn from the stress of the damage and take advantage of windows of opportunity for more effective adaptive risk management. The decision to relocate could be either be interpreted as learning from stresses and seeking to take on an adaptive response or as a break or phase change in the system structure where residency in the neighborhood is replaced by non-residency (i.e., moving away).

To examine these different dimensions, three sets of resiliency-related variable attributes are compared for the three groups households. These variables include: conditions of stress (Table 5a), resources available after the storm (Table 5b) and capacity to activate resource (Table $5 \mathrm{c}$ ).

\section{Stress Conditions}

Some specific significant differences with respect to the level of stress faced in the post disaster context were present between those seeking a buyout and those remaining. Most importantly, those seeking a buy outwere more likely to have evacuated during Sandysuffered longer dislocation, and had homes that they considered now uninhabitable even though the average amount of damage was roughly comparable to the other two groups of households (e.g. $\sim \$ 93,466$ USD which was the middle value of the three groups).

\section{Resources Available}

With respect to the amount of resources available, significant difference were found among the three groups. Those bouncing back and simply rebuilding, while having only slightly incomes than the other two groups, had significantly lower amounts of insurance compensation. Those seeking a buyout (i.e. bouncing away) were longer-term residents with smaller households and possibly most significantly were more likely to perceive their social networking as changed (either positively or negatively).

\section{Capacity to Respond}

The third comparative analysis highlights the most consistent difference between those residents remaining in the neighborhoods and those deciding to move away. Those relocating were spent months deciding what to do while those remaining took 1.5 to 3 weeks to decide. And, those relocating also were much more likely to go back and forth in their decision as to remain or leave than the those bouncing forward but at a level that was comparable to those just rebuilding (bouncing back). It is interesting to note that those simply rebuilding had some early indecisiveness but once they decided to stay they typically remained with that decision. Those rebuilding with advancing resiliency seemed to experience little change in the quality of their social networks and information accessed while the other two groups (bouncing back and bouncing away) experience a lot of change with one group experiencing a decline or diminishment and one experiences a gain or increase in social networking quality. All groups seemed to indicate that the change in network quality remained consistent over time in the post disaster period.

\section{Conclusions}

Hurricane Sandy was a transformative event for the communities along the shores of Raritan Bay. The study reveals that the decisions that households made in the year following the storm were deeply embedded in their own experiences and in the context of the neighborhood. The survey results illustrate the connections between the households and the communities in which they lived were significant. These connections influenced the conditions of resilience of the households in the post extreme event context and the likelihood of a household deciding to seek a buyout (i.e., here defined as a system level transition).

Those seeking a buyout in general were the longer-term, older residents who had to evacuate for an extended time. What is particularly interesting about the buyout group was they took a much longer time to decide and were much more likely to switch back and forth in their decision to leave the neighborhood - both conditions are very reflective of a system undergoing a transition. A crucial element in their decision-making was the structure and availability of information from government sources while those remaining relied more heavily on non-governmental information (e.g. from neighbors and other local sources). Taken together, this is evidence that the systems level resiliency analytical approach used in the study was effective in helping to understand the differences between the three groups of households - i.e., those bouncing back, those bouncing forward, and those bouncing away (i.e. in buyout transition).

This analysis provides critical new knowledge aboutresiliency that might promote or hinder significant household and neighborhood change in the post extreme event context. Agrowing recognition exists that coastal properties and communities cannot be rebuilt with the simple goal of reducing vulnerability to the last event and that the rebuilding effort must attempt to encourage the building of resilience capacity both within individual households and neighborhoods (Solecki \& Rosenzweig 2014). The results illustrate, for example, that the early government response and information flow influenced the decision-making processes of residents seeking to relocation via buyout program. As gleaned from individual household residents' responses, other residents (e.g. those not seeking a buyout) felt that the government responses in the area had not been successful with engaging with communities and that no coherent process existedto help those with limited income (i.e., lower resource capacity). How coastal areas can respond to these kinds of post disaster stresses remains a question for the future?

Overall, the results highlight the importance of new research to contribute to better understand of these post disaster, climate change contexts. The leading edge of climate change experience for communities and households will be extreme events and they are projected to become more frequent in the future. Understanding how individuals and institutions are responding to climate change in this context will be critical for the development of new post-disaster learning and decision-making support systems. 
MISCELLANEA GEOGRAPHICA - REGIONAL STUDIES ON DEVELOPMENT

Vol. $21 \cdot$ No. 4 • $2017 \cdot$ pp. 139-150 • ISSN: 2084-6118 • DOI: 10.1515/mgrsd-2017-0029

Table 5a. Condition of stress facing households

\begin{tabular}{|c|c|c|c|c|c|}
\hline & Damage - USD & $\begin{array}{c}\text { Home } \\
\text { Uninhabitable after } \\
\text { Storm - \% }\end{array}$ & $\begin{array}{c}\text { Length of Days } \\
\text { Dislocated }\end{array}$ & Still Dislocated - \% & $\begin{array}{c}\text { Evacuated During } \\
\text { Sandy -\% }\end{array}$ \\
\hline Bouncing Back & 98174.0 & 65.0 & 62.7 & 8.0 & 33.0 \\
\hline Bouncing Forward & 132903.0 & 56.0 & 124.0 & 11.0 & 56.0 \\
\hline In Transition & 115260.0 & 95.0 & 142.0 & 20.0 & 75.0 \\
\hline & $\begin{array}{c}\text { Uncovered Loss } \\
\text { and Damage }\end{array}$ & $\begin{array}{c}\text { Local Information } \\
\text { Quality }\end{array}$ & $\begin{array}{c}\text { Concern over Loss } \\
\text { of Community }\end{array}$ & $\begin{array}{c}\text { Concern over } \\
\text { Paying Bill }\end{array}$ & $\begin{array}{c}\text { Concern over } \\
\text { Dislocation }\end{array}$ \\
\hline Bouncing Back & 78193.0 & 3.1 & 2.8 & 2.5 & 2.4 \\
\hline Bouncing Forward & 105474.0 & 3.7 & 3.3 & 3.2 & 3.4 \\
\hline In Transition & 93466.0 & 3.1 & 3.2 & 2.3 & 1.7 \\
\hline
\end{tabular}

Table 5b. Resources available after the storm

\begin{tabular}{|c|c|c|c|c|c|c|}
\hline & $\begin{array}{c}\text { Household } \\
\text { Mean Income }\end{array}$ & $\begin{array}{c}\text { Years Owned } \\
\text { Property }\end{array}$ & $\begin{array}{c}\text { With H.S. } \\
\text { degree - \% }\end{array}$ & $\begin{array}{c}\text { Number in } \\
\text { Household }\end{array}$ & $\begin{array}{c}\text { Household } \\
\text { Savings Used }\end{array}$ & $\begin{array}{c}\text { Insurance } \\
\text { Compensation }\end{array}$ \\
\hline Bouncing Back & 89868.0 & 18.0 & 38.0 & 3.3 & 19981.0 & 42805.0 \\
\hline Bouncing Forward & 81429.0 & 12.8 & 33.0 & 4.6 & 27429.0 & 68350.0 \\
\hline In Transition & 83036.0 & 27.4 & 55.0 & 2.7 & 21794.0 & 56542.0 \\
\hline & $\begin{array}{c}\text { Number of } \\
\text { Information } \\
\text { Sources Used }\end{array}$ & $\begin{array}{c}\text { Information } \\
\text { Gathering }\end{array}$ & $\begin{array}{c}\text { Value of } \\
\text { Information }\end{array}$ & $\begin{array}{c}\text { Social Network } \\
\text { Remained } \\
\text { Same- \% }\end{array}$ & $\begin{array}{c}\text { Social Network } \\
\text { Became Less } \\
\text { Diverse - \% }\end{array}$ & $\begin{array}{c}\text { Social Network } \\
\text { Became More } \\
\text { Diverse - \% }\end{array}$ \\
\hline Bouncing Back & 6.5 & 2.8 & 2.9 & 52 & 5 & 36 \\
\hline Bouncing Forward & 8.4 & 3.1 & 2.7 & 78.0 & 0.0 & 22.0 \\
\hline In Transition & 7.9 & 3.1 & 2.6 & 32.0 & 26.0 & 42.0 \\
\hline
\end{tabular}

Notes

a. range from 0 to 11

b. 1 - never; 5 often

c. 1 -not very; 5 very useful

Table 5c. Capacity to activate resources

\begin{tabular}{|c|c|c|c|c|c|c|c|}
\hline & $\begin{array}{c}\text { Days to } \\
\text { Decision Stay } \\
\text { or Sell }\end{array}$ & $\begin{array}{l}\text { Percent } \\
\text { Decided } \\
\text { and Never } \\
\text { Changed }\end{array}$ & $\begin{array}{c}\text { Percent Less } \\
\text { Certain Over } \\
\text { Time }\end{array}$ & $\begin{array}{c}\text { Percent More } \\
\text { Certain Over } \\
\text { Time }\end{array}$ & $\begin{array}{l}\text { Percent Went } \\
\text { Back and } \\
\text { Forth }\end{array}$ & \begin{tabular}{|c|} 
Quality of \\
Social Network \\
- Remained \\
Same \\
\end{tabular} & $\begin{array}{c}\text { Quality of } \\
\text { Social Network } \\
\text { - Became Less }\end{array}$ \\
\hline $\begin{array}{c}\text { Bouncing } \\
\text { Back }\end{array}$ & 19.8 & 64 & 4 & 4 & 32 & 60 & 5 \\
\hline $\begin{array}{l}\text { Bouncing } \\
\text { Forward }\end{array}$ & 10.6 & 67 & 0 & 22 & 11 & 67 & 0 \\
\hline \multirow[t]{2}{*}{ In Transition } & 113.7 & 26 & 0 & 32 & 42 & 63 & 5 \\
\hline & $\begin{array}{c}\text { Quality of } \\
\text { Social Network } \\
\text { - Became More }\end{array}$ & \begin{tabular}{|} 
Usefulness of \\
Social Network \\
- Remained \\
Same
\end{tabular} & $\begin{array}{l}\text { Usefulness of } \\
\text { Social Network } \\
\text { - Became Less }\end{array}$ & $\begin{array}{l}\text { Usefulness of } \\
\text { Social Network } \\
\text { - Became More }\end{array}$ & \begin{tabular}{|c|} 
Change of \\
Social Network \\
on Decision \\
to Relocate \\
- Remained \\
Same
\end{tabular} & $\begin{array}{c}\text { Change of } \\
\text { Social Network } \\
\text { on Decision } \\
\text { to Relocate - } \\
\text { Became Less }\end{array}$ & $\begin{array}{l}\text { Change of } \\
\text { Social Network } \\
\text { on Decision } \\
\text { to Relocate - } \\
\text { Became More }\end{array}$ \\
\hline $\begin{array}{c}\text { Bouncing } \\
\text { Back }\end{array}$ & 35 & 43 & 5 & 52 & 67 & 14 & 10 \\
\hline $\begin{array}{l}\text { Bouncing } \\
\text { Forward }\end{array}$ & 33 & 78 & 0 & 22 & 78 & 22 & 0 \\
\hline In Transition & 32 & 42 & 21 & 37 & 63 & 16 & 16 \\
\hline
\end{tabular}


Adger, N, Quinn, T, Lorenzoni, I \& Murphy, C 2016, 'Sharing the pain: perception of fairness affect private and public response to hazards', Annals of the American Association of Geographers, vol. 106(5), pp. 1079-1096.

Aerts, JC, Lin, N, Botzen, W, Emanuel, K \& de Moel, H 2013, 'Low probability flood risk modeling for New York City', Risk Analysis, vol. 33(5), pp. 772-788.

Ankum, L, Brocken W \& Koch, T 2016, “Don't count on living in Miami": a human geographical approach to understanding the ramifications of sea level rise for urban Miami, Sea Level Rise Collection. Available from: <http://digitalcommons.fiu. edu/sea_level_rise/52>.

Associated Press-NORC Center for Public Affairs Research. 2013. Resilience in the Wake of Superstorm Sandy. Available from: <http://www.apnorc.org/projects/pages/ resilience-in-the-wake-of-superstorm-sandy.aspx>.

Binder, SB, Baker, CK \& Barlie, JP 2015, 'Rebuild or relocate? Resilience and post disaster decision-making after Hurricane Sandy', American Journal of Community Psychology, vol. 56, pp. 180-196. DOI 10.1007/s10464-015-9727-x.

Blake, ES, Kimberlain, TB, Berg, RJ, Cangialosi, JP \& Beven, II JL, 2013, Tropical Cyclone Report: Hurricane Sandy (AL182012), National Hurricane Center.

Burton, I, Kates, R \& White, G 1993, Environment as Hazard, $2^{\text {nd }}$ edition, New York, Guilford Press.

Carpenter, SR \& Scheffer, M 2009, 'Critical transitions and regime shifts in ecosystems: consolidating recent advances' in New Models for Ecosystem Dynamics and Restoration, eds RJ Hobbs \& KN Suding, Washington, DC, Island Press.

Folke, C 2006, 'Resilience: the emergence of a perspective for social-ecological systems analyses', Global Environmental Change, vol. 16(3), pp. 253-267.

Forestall, R 1996, Population of states and counties of the United States: 1790 to 1990 from the twenty-one Decennial Censuses, Washington DC, United States Census Bureau.

Gruebner, O, Lowe, SR, Sampson, L \& Galea, S 2015, 'The geography of post-disaster mental health: Spatial patterning of psychological vulnerability and resilience factors in New York City after Hurricane', International Journal of Health Geographics, vol. 14, p. 16. DOI 10.1186/s12942-015-00086.

Gunderson, LH \& Pritchard, L 2002 Resilience and the behavior of large-scale systems, Washington, DC, Island Press.

Gunderson, LH \& Holling, CS 2001, Panarchy: Understanding transformations in human and natural systems, Washington, DC, Island Press.

Hall, TM \& Sobel, AH 2013, 'On the impact angle of Hurricane Sandy's New Jersey landfall', Geophysical Letters, vol. 40, pp. 2312-2315.

Hamilton, LC, Saito, K, Loring, PA, Lammers, RB \& Huntington, HP 2016, 'Climigration? Population and climate change in Arctic Alaska', Population and Environment, vol. 38, pp. 115-133. DOI 10.1007/s11111-016-0259-6.

Hauer, ME, Evans, HM \& Mishra, DR 2016, 'Millions projected to be at risk from sea-level rise in the continental United States', Nature Climate Change, vol. 6, pp. 691-695. DOI: 10.1038/NCLIMATE2961.

Hewitt, K (ed.) 1983, Interpretations of Calamity, London, Unwin and Allen.

Hughes, CJ 2015, 'New Dorp, Staten Island: Still Recovering from Sandy', New York Times. 12 August. Available from: <https://www.nytimes.com/2015/08/16/realestate/new-dorp-
staten-island-still-recovering-from-sandy.html?module=Arro wsNav\&contentCollection=Real\%20Estate\&action=keypres s\&region=FixedLeft\&pgtype=article $>$. [16 August 2015]

Johnson, M 2010, 'Midland Beach' in The Encylopedia of New York City ( $2^{\text {nd }}$ edition), eds KT Jackson, L Keller \& N Flood, New Haven, Yale University Press.

Koslov, L 2014, 'Fighting for retreat after Sandy: The Ocean Breeze buyout tent on Staten Island', Metropolitiques.eu, 23 April. Available from: <http://www.metropolitiques.eu/ Fighting-for-Retreat-after-Sandy.html?lang=fr $>$.

Lathro, R \& Hasse, J 2006, 'Tracking New Jersey's changing landscape', New Jersey's Environments: Past, Present, and Future, pp. 111-127. New Brunswick, Rutgers University Press.

Lenton, TM 2011, 'Early warning of climate tipping points', Nature Climate Change, vol. 1, pp. 201-209.

Lowe, SR, Sampson, L, Gruebner, O \& Galea, S 2015 'Psychological Resilience after Hurricane Sandy: The Influence of Individual- and Community-Level Factors on Mental Health after a Large-Scale Natural Disaster', PLOS ONE, vol. 10(5). Available from: <https://doi.org/10.1371/ journal.pone.0125761>

MacKenzie, C 1992, The Fisheries of Raritan Bay, New Brunswick, Rutgers University Press.

Maher, NM 2006, 'Introduction: Nature's next exit? Or why New Jersey is as important as Yellowstone National Park' in New Jersey's Environments: Past, Present, and Future, ed NM Maher, pp. 1-10, New Brunswick, Rutgers University Press

Maly, E \& Ishikawa, E 2013, 'Land acquisition and buyouts as disaster mitigation after Hurricane Sandy in the United States', Proceeding of International Symposium on City Planning, p. 18. Available from: <www1.cpij.or.jp/com/iac/ sympo/13/ISCP2013-8.pdf>.

McCay, BJ 1998, Oyster wars and the public trust: Property, law, and ecology in New Jersey history, Tuscan, University of Arizona Press.

Mitchell, JK 2006, 'A century of natural disasters in a stat of change. Tracking New Jersey's changing landscape' in New Jersey's Environments: Past, Present, and Future, ed NM Maher, New Brunswick, Rutgers University Press.

Nakayama, M, Fujibayashi, H \& Yoshioka, N 2016, 'Applying past lessons learned to the relocation of climate change induced transboundary displaced person', International Journal of Social Science Research, vol. 4(2), pp. 66-77.

New Jersey Department of Community Affairs 2013, Community Development Block Grant Disaster Recovery Action Plan, Trenton, New Jersey.

New York City Panel on Climate Change 2013, Climate Risk Information 2013: Observations, Climate Change Projections, and Maps, Prepared for use by the City of New York Special Initiative on Rebuilding and Resiliency, New York, New York.

New York City Panel on Climate Change 2015, A Knowledge Base for Climate Resilience in New York City: Post-Hurricane Sandy Science and Assessment, ed C Rosenzweig \& W Solecki, New York Academy of Sciences.

Pelling, M, O'Brien, K \& Matyas, D 2015, 'Adaptation and transformation', Climatic Change, vol. 33(1), pp. 113-127.

Rebuild by Design 2015, Rebuild by Design, New York, Fergus.

Relph, E 1976, Place and Placelessness, London, Pion.

Rosenzweig, C \& Solecki, W 2014, 'Hurricane Sandy and adaptation pathways in New York: Lessons from a first- 
responder city', Global Environmental Change. Available from: <http://dx.doi.org/10.1016/j.gloenvcha.2014.05.003>.

Sayreville Historical Society n.d., Industries. Available from: $<$ http://www.sayrevillehistory.org/\#! industries/c1r2u. Accessed: 7/17/2014>.

Scheffer, M 2009, Critical transitions in nature and society, Princeton, Princeton University Press.

Scheffer, M, Carpenter, SR, Lenton, TM, Bascompte, J, Brock W, Dakos, V, van De Koppel J, van De Leemput, IA, Levin, SA, van Nes, EH \& Pascual, M 2012, 'Anticipating critical transitions', Science, vol. 338(6105), pp. 344-348.

Solecki, W, Pelling, M \& Garschagen, M 2017, 'A framework for urban risk management regime shifts', Ecology \& Society, vol. 22(2), p. 38.

Solecki, W, O’Brien, K \& Leichenko, R 2011, 'Disaster Risk Reduction and Climate Change Adaptation Strategies: Convergence and Synergies', Current Opinion in Environmental Sustainability, vol. 3(3), pp. 135-141.

Sparberg, A 2010, 'Oakwood Beach' in The Encylopedia of New York City ( $2^{\text {nd }}$ edition), ed KT Jackson, L Keller \& N Flood, New Haven, Yale University Press.

Special Initiative for Rebuilding and Resiliency (SIRR) 2013, A Strong, More Resilient New York, The City of New York. Available from: <http://www.nyc.gov/html/sirr/html/report/ report.shtml>.

Toffelfson, J 2013, 'New York vs. the sea', Nature, 14 February. Available from: <https://www.nature.com/news/naturalhazards-new-york-vs-the-sea-1.12419>.

Tompson, T, Benz, J, Agiesta, J, Cagney, K \& Meit, M 2013 Resilience in the Wake of Superstorm Sandy, The Associated Press-NORC, Center for Public Affairs Research

Vasilogambros, M 2016, Taking the High Ground-and Developing It. The Atlantic. Available from: <https://www. theatlantic.com/business/archive/2016/03/taking-the-highground-and-developing-it/472326/>.

Walker, B, Holling, CS, Carpenter, SR \& Kinzing, A 2004 'Resilience, adaptability and transformability in socialecological systems', Ecology \& Society, vol. 9(2), p. 5. Available from: <http://www.ecologyandsociety.org/vol9/ iss $2 /$ art $5 />$

Wisner, B, Blaikie, P, Cannon, T \& Davis, I 2004, At Risk: Natural Hazards, People's Vulnerability and Disasters, New York, Routledge. 